This article is licensed under the Creative Commons Attribution-NonCommercial 4.0 International License (CC BY-NC) (http://www.karger.com/Services/OpenAccessLicense). Usage and distribution for commercial purposes requires written permission.

\title{
An Unusual Differential Diagnosis of Orbital Cavernous Hemangioma: Ancient Schwannoma
}

\author{
Sara Filipa Teixeira Ribeiro ${ }^{a, b} \quad$ Tatiana Queirós $^{a} \quad$ José M. Amorim ${ }^{c}$ \\ Ana M. Ferreira ${ }^{d}$ Marco Sales-Sanz $^{e}$ \\ a Orbit and Oculoplastic Surgery Unit, Ophthalmology Department, Hospital de Braga, \\ School of Health Sciences, University of Minho, Braga, Portugal; ${ }^{b}$ Ophthalmology \\ Department, Hospital Lusíadas, Porto, Portugal; ${ }^{C}$ Neuroradiology Department, Hospital de \\ Braga, Braga, Portugal; ${ }^{d}$ Pathologic Anatomy Department, Hospital de Braga, \\ Braga, Portugal; ${ }^{e}$ Orbit and Oculoplastic Surgery Unit, Ophthalmology Department, \\ Hospital Universitario Rámon y Cajal, IRYCIS, Oculoplastic Surgery Unit, Novovision, \\ Madrid, Spain
}

\section{Keywords}

Schwannoma - Orbit · Ancient schwannoma - Neurilemmoma - Orbital tumors · Peripheral nerve sheath tumor

\begin{abstract}
Schwannomas are rare lesions of the orbit that can be confused with cavernous hemangioma on imaging studies. We report the case of an 84-year-old woman with a 9-year history of a tumoral lesion in the inferolateral left orbit. The imaging studies did not reveal specific characteristics, only bone remodeling due to the long evolution of the tumor. The patient underwent complete excision of the tumor by anterior orbitotomy via the inferior conjunctival fornix. The histopathological examination revealed an ancient schwannoma, a variant of schwannoma with uncommon histological features. The follow-up was uneventful. The present case emphasizes the importance of considering neural tumors in the differential diagno-
\end{abstract}


sis of orbital masses with bone changes and degenerative alterations such as hemorrhagic areas, cysts, and/or calcifications.

\section{Introduction}

Schwannomas of the orbit are rare lesions comprising approximately $1 \%$ of orbital tumors [1]. The ancient schwannoma is a rare variant of schwannoma with a typical slowgrowing benign course and particular histopathological features. We detected only 6 cases of these tumors in the literature [2-7] (Table 1). The literature search was performed on the MEDLINE database using the keywords "schwannoma," "ancient schwannoma," "neurilemmoma," and "orbit." Only articles in English were included.

We report here an unusual case of orbital ancient schwannoma mimicking an orbital cavernous hemangioma. Note its particular features, namely the presence of bone remodeling and nuclear and hemorrhagic degeneration.

\section{Results/Case Report}

An 84-year-old woman presented with a 9-year history of progressive protrusion, deterioration of visual acuity, redness, watering, and lower eyelid malposition of her left eye. Upon inspection, the left globe was displaced superiorly and anteriorly and a mechanical lower eyelid ectropion was present. Palpation showed a firm, easily mobile mass in the inferolateral left orbit. The mass was nonpulsatile and did not vary with posture, ocular movements, or Valsalva maneuver. Examination revealed normal pupil reactions and diplopia in all eye positions. The best-corrected visual acuities were $9 / 10$ in the right eye and $4 / 10$ in the left eye. Exophthalmometry (Hertel exophthalmometer) was $14 \mathrm{~mm}$ in the right eye and $22 \mathrm{~mm}$ in the left eye. Biomicroscopy, intraocular pressure, and fundoscopy were normal. The right eye and systemic evaluation were unremarkable. Computed tomography (CT) scans revealed a large, well-demarcated, oval mass in the intraconal space of the left inferolateral orbit, which was isodense compared to the extraocular muscles (Fig. 1). There was discrete bone remodeling. Magnetic resonance imaging (MRI) showed an intraconal lesion in the left inferolateral orbit with well-defined margins and an oval shape (Fig. 1). The major axis measured $33 \times 24 \mathrm{~mm}$. On T1-weighted images, the lesion showed isointensity in relation to muscle and a heterogeneous but mostly hyperintense signal on T2-weighted images. T2 gradient-echo images showed a central hypointense component suggesting the presence of micro-hemorrhages. On contrast-enhanced images, the lesion showed a progressive and heterogeneous enhancement with a more vivid central region. A diagnosis of cavernous hemangioma was made based on the clinical and imaging features. The patient underwent an anterior orbitotomy via the inferior conjunctival fornix. The mass was purpleyellowish, with a smooth surface and well encapsulated, with no infiltration of surrounding soft tissues (Fig. 2). The tumor was completely excised without damaging the capsule. The histopathological diagnosis of the lesion was an ancient schwannoma (Fig. 2). The mass 


\section{Case Reports in Ophthalmology}

Case Rep Ophthalmol 2017;8:294-300

DOI: $10.1159 / 000473697$

(C) 2017 The Author(s). Published by S. Karger AG, Base www.karger.com/cop

Ribeiro et al.: An Unusual Differential Diagnosis of Orbital Cavernous Hemangioma: Ancient Schwannoma

measured $35 \mathrm{~mm}$ in its largest dimension. Microscopically, the tumor was composed of hypercellular (Antoni A, predominant) and hypocellular (Antoni B) areas. The lesion presented degenerative changes such as nuclear atypia (pleomorphic, hyperchromatic nuclei and nuclear pseudoinclusions) and hemorrhagic areas. Immunohistochemical study revealed strong positive staining for S-100 protein in tumor cells (Fig. 2). On follow-up at 3 months, the patient was asymptomatic, with no evidence of tumor recurrence. The mechanical lower eyelid inferior ectropion resolved spontaneously.

\section{Discussion}

Orbital schwannomas are benign, often unilateral and originate from Schwann cells. They usually arise from sensory nerves, although some cases have been reported to derive from motor nerves. In the orbit, they usually arise from branches of the supraorbital or supratrochlear nerves and less commonly from the infraorbital, ciliary, oculomotor, trochlear, abducens, or optic nerves. In about $50 \%$ of cases, its origin remains obscure [2, 4, 6, 8-10]. The ancient schwannoma is an uncommon histological variant of schwannoma. The term "ancient schwannoma" was coined by Ackerman in 1951 to describe these tumors in the thorax [11].

Clinical features may include progressive proptosis, optic neuropathy, diplopia, numbness, and pain. There are no clinical or radiographic pathognomonic features differentiating schwannomas from other well-circumscribed orbital lesions such as cavernous hemangioma, fibrous histiocytoma, neurofibroma, hemangiopericytoma, solitary fibrous tumor, and others. A definitive diagnosis can only be made on histopathology [4-10]. Histopathological examination reveals that schwannomas are characterized by hypercellular (Antoni A) and hypocellular (Antoni B) areas. Areas of increased cellularity with nuclear atypia (pleomorphic, hyperchromatic, multilobulated nuclei) alternate with hypocellular areas with considerable fibrosis. Despite nuclear atypia, mitotic figures are absent. Immunohistochemical testing is usually positive for vimentin, neuron-specific enolase, and S-100 protein and negative for cytokeratin $[2,4,7,10]$. Degenerative findings such as hemorrhage, cyst formation, focal calcification, and perivascular hyalinization are indicative of the long duration of the tumor and are characteristic of the so-called "ancient schwannomas" [2-7, 10]. The hypercellularity and nuclear atypia frequently present in ancient schwannomas may lead to the erroneous interpretation of a malignant tumor $[2,10]$. Complete surgical excision was curative in all reported cases and malignant change was never seen in ancient orbital schwannomas $[2-7,9]$.

We believe that this case improves the knowledge about orbital tumors. We report here for the first time bone remodeling in an orbital ancient schwannoma with 9 years of evolution and with a detailed MRI description. The present case shows that tumors of the peripheral nervous system should be considered in the differential diagnosis of orbital masses with bone changes. 
Ribeiro et al.: An Unusual Differential Diagnosis of Orbital Cavernous Hemangioma:

Ancient Schwannoma

\section{Statement of Ethics}

Written informed consent was obtained from the patient for publication of this case report and accompanying images.

\section{Disclosure Statement}

The authors have no financial disclosure.

\section{References}

1 ZA K: Orbital Tumors: Diagnosis and Treatment. New York, Springer, 2004

-2 Khwarg SI, Lucarelli MJ, Lemke BN, Smith ME, Albert DM: Ancient schwannoma of the orbit. Arch Ophthalmol 1999;117:262-264.

3 Moloney G, Brewer J, O’Donnell BA: "Ancient" schwannoma of the orbit. Clin Exp Ophthalmol 2004;32:637-638.

4 Sales-Sanz M, Sanz-Lopez A, Romero JA: Bilateral simultaneous ancient schwannomas of the orbit. Ophthal Plast Reconstr Surg 2007;23:68-69.

5 de Jong L, Demaerel P, Sciot R, Van Calenbergh F: A patient with swelling of the eyelid: ancient schwannoma of the supraorbital nerve (2010:6b). Eur Radiol 2010;20:2301-2304.

Pecorella I, Toth J, Lukats O: Ancient schwannoma of the orbit. Pathologica 2012;104:182-184.

Kulkarni AS, Anjum S, Kokandakar HR, Bindu RS, Awargaonkar A: Ancient schwannoma of the orbit. Oman J Ophthalmol 2014;7:66-68.

-8 Cockerham KP, Cockerham GC, Stutzman R, Hidayat AA, Depper MH, Turbin RE, et al: The clinical spectrum of schwannomas presenting with visual dysfunction: a clinicopathologic study of three cases. Surv Ophthalmol 1999;44:226-234.

-9 Pushker N, Khurana S, Kashyap S, Sen S, Shrey D, Meel R, et al: Orbital schwannoma: a clinicopathologic study. Int Ophthalmol 2015;35:481-486.

$\checkmark 10$ Sweeney AR, Gupta D, Keene CD, Cimino PJ, Chambers CB, Chang SH, et al: Orbital peripheral nerve sheath tumors. Surv Ophthalmol 2017;62:43-57.

11 Ackerman LV, Taylor FH: Neurogenous tumors within the thorax; a clinicopathological evaluation of forty-eight cases. Cancer 1951;4:669-691. 


\section{Case Reports in Ophthalmology}
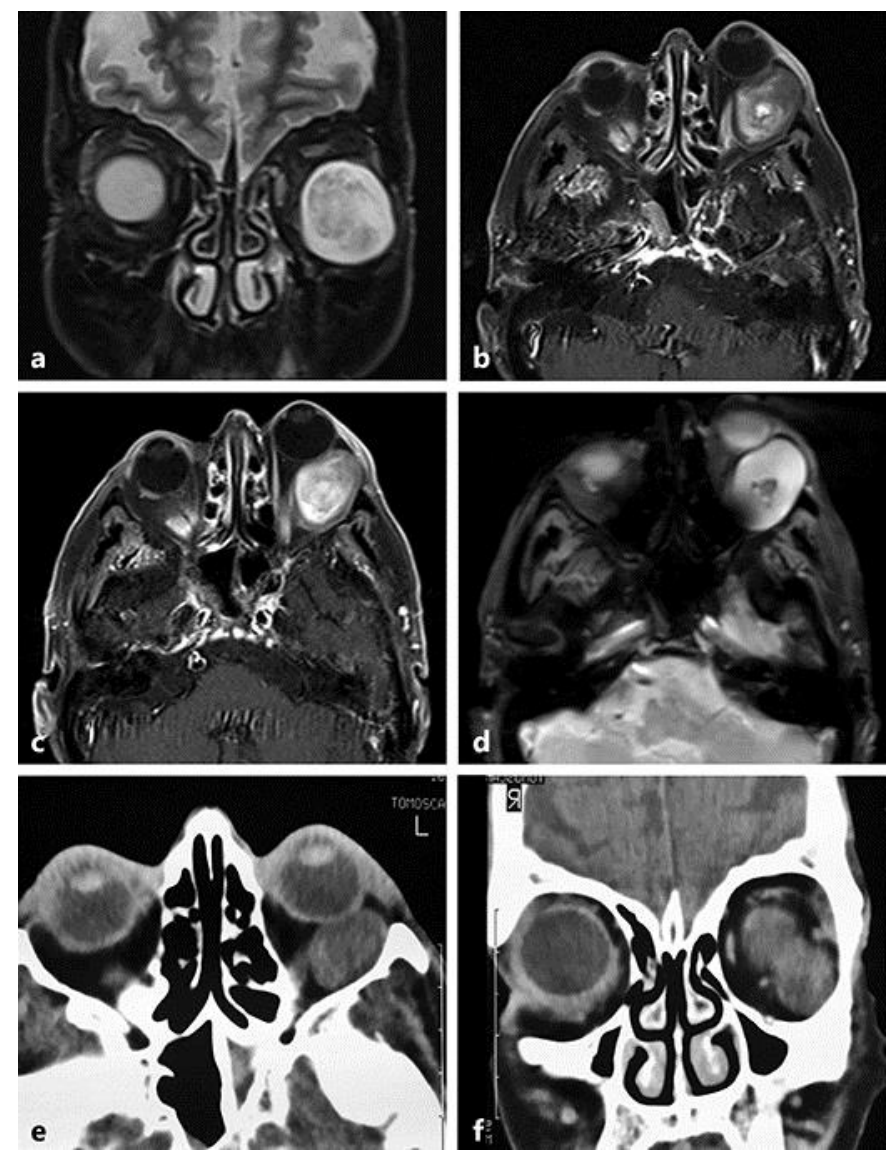

Fig. 1. MRI showed a well-defined, oval, intraconal lesion in the left inferolateral orbit. Axial T1-weighted image shows isointensity in relation to muscle. Coronal T2-weighted image shows a heterogeneous but mostly hyperintense signal (a). Axial post-contrast fat saturated T1-weighted images (b, c axial scans) show a progressive and heterogeneous enhancement with a more vivid central region. Axial T2 gradientecho image (d) shows a central hypointense component suggesting the presence of micro-hemorrhages. CT scans (e axial; f coronal) revealed a large, well-demarcated, oval mass, isodense compared to the extraocular muscles in the intraconal space of the left inferolateral orbit; there was discrete bone remodeling. 


\section{Case Reports in Ophthalmology}

Case Rep Ophthalmol 2017;8:294-300
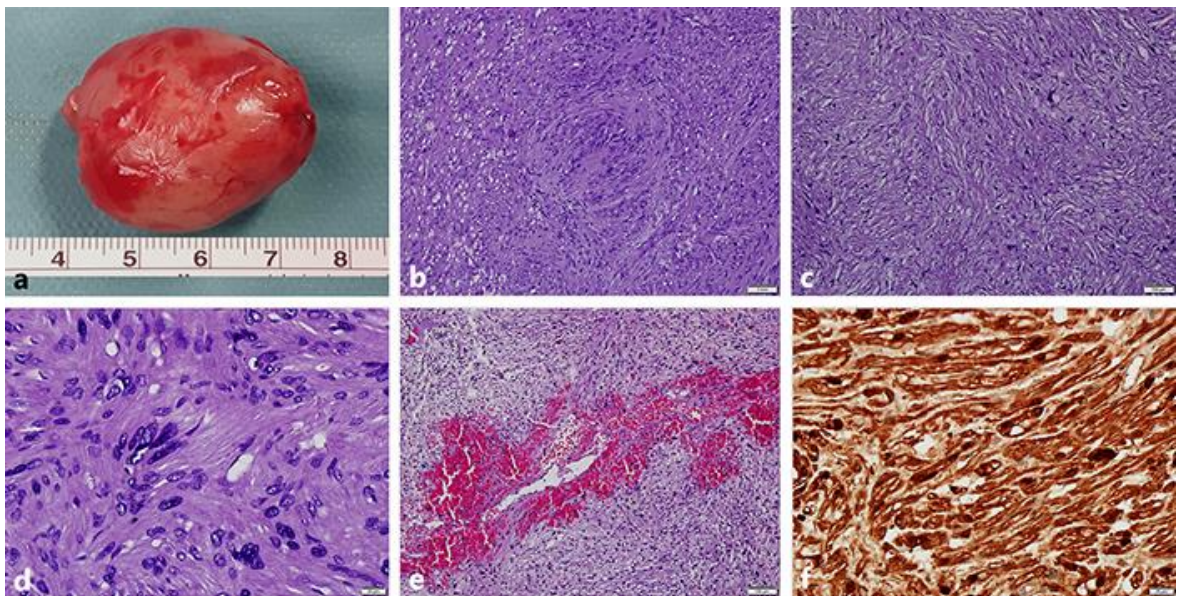

Fig. 2. Orbital ancient schwannoma. a Macroscopic aspect: purple-yellowish mass, with a smooth surface and well encapsulated. Histopathological examination: Antoni A area, hypercellular with a Verocay body (b HE. ×100); Antoni B area, hypocellular (c HE. ×100); nuclear atypia (d HE. $\times 400)$, and hemorrhagic degeneration (e HE. $\times 100)$. $\mathbf{f}$ Immunohistochemical staining revealing positivity for S-100 protein. S-100. $\times 400$. 
Ribeiro et al.: An Unusual Differential Diagnosis of Orbital Cavernous Hemangioma:

Ancient Schwannoma

Table 1. Cases of orbital ancient schwannoma reported in the literature

\begin{tabular}{|c|c|c|c|c|c|c|c|c|}
\hline $\begin{array}{l}\text { First } \\
\text { author } \\
\text { [Ref.], } \\
\text { year }\end{array}$ & $\begin{array}{l}\text { Gender/ } \\
\text { age, } \\
\text { years }\end{array}$ & $\begin{array}{l}\text { Clinical } \\
\text { presentation }\end{array}$ & $\mathrm{CT}$ & MRI & Localization & $\begin{array}{l}\text { Hystological } \\
\text { findings }\end{array}$ & $\begin{array}{l}\text { Complete } \\
\text { excision }\end{array}$ & $\begin{array}{l}\text { Recurrence/ } \\
\text { follow-up }\end{array}$ \\
\hline $\begin{array}{l}\text { Khwarg [2 } \\
1999\end{array}$ & , F/52 & $\begin{array}{l}\text { Epiphora } \\
\text { Exophthalmos }\end{array}$ & $\begin{array}{l}\text { Well-demarcated, } \\
\text { oval, nonenhancing } \\
\text { mass }\end{array}$ & NS & $\begin{array}{l}\text { Intraconal } \\
\text { Inferolateral }\end{array}$ & $\begin{array}{l}\text { Nuclear pleomorphism } \\
\text { Hyperchromatism } \\
\text { Nuclear atypia } \\
\text { Areas of hyper- and } \\
\text { hypocellularity }\end{array}$ & Yes & NS \\
\hline $\begin{array}{l}\text { Moloney } \\
{[3]} \\
2004\end{array}$ & $\mathrm{~F} / 65$ & $\begin{array}{l}\text { Discomfort } \\
\text { Protrusion }\end{array}$ & $\begin{array}{l}\text { Large, round } \\
\text { mass }\end{array}$ & NS & $\begin{array}{l}\text { Extraconal } \\
\text { Superolateral }\end{array}$ & $\begin{array}{l}\text { Cystic } \\
\text { Haemosiderin } \\
\text { pigment deposition } \\
\text { Nuclear atypia }\end{array}$ & Yes & No/6 months \\
\hline $\begin{array}{l}\text { Sales- } \\
\text { Sanz [4], } \\
2007\end{array}$ & $\mathrm{~F} / 49$ & $\begin{array}{l}\text { Progressive } \\
\text { inferior orbital } \\
\text { fat prolapse }\end{array}$ & $\begin{array}{l}\text { Bilateral, } \\
\text { heterogeneous, } \\
\text { well-demarcated } \\
\text { masses }\end{array}$ & NS & $\begin{array}{l}\text { Extraconal } \\
\text { Inferior }\end{array}$ & $\begin{array}{l}\text { Antoni A and } \\
\text { Antoni B areas } \\
\text { Cystic } \\
\text { IH - S-100 protein } \\
\text { positive }\end{array}$ & Yes & No/16 months \\
\hline $\begin{array}{l}\text { de Jong } \\
{[5],} \\
2010\end{array}$ & $\mathrm{M} / 44$ & $\begin{array}{l}\text { Upper eyelid } \\
\text { swelling } \\
\text { Anesthesia of } \\
\text { supraorbital } \\
\text { region }\end{array}$ & $\begin{array}{l}\text { Tumor located } \\
\text { above the rectus } \\
\text { superior and } \\
\text { levator palpebrae } \\
\text { muscles }\end{array}$ & $\begin{array}{l}\text { T1: hypointense } \\
\text { with a peripheral } \\
\text { enhancing rim } \\
\text { T2: fluid-fluid level, } \\
\text { representing } \\
\text { hemorrhage within } \\
\text { a central cystic lesion }\end{array}$ & $\begin{array}{l}\text { Extraconal } \\
\text { Superior }\end{array}$ & $\begin{array}{l}\text { Hemorrhage } \\
\text { Hemosiderotic or foamy } \\
\text { macrophages } \\
\text { Cystic degeneration } \\
\text { IH - S-100 protein } \\
\text { positive }\end{array}$ & Yes & NS \\
\hline $\begin{array}{l}\text { Pecorella } \\
{[6],} \\
2012\end{array}$ & $\mathrm{~F} / 32$ & $\begin{array}{l}\text { Inferior eyelid } \\
\text { swelling } \\
\text { Proptosis }\end{array}$ & $\begin{array}{l}1 \mathrm{~cm} \text { localized } \\
\text { homogeneous oval } \\
\text { mass below the globe } \\
\text { at the level } \\
\text { of the inferior } \\
\text { orbital rim }\end{array}$ & $\begin{array}{l}\text { T1: moderate signal } \\
\text { intensity in the lesion; } \\
\text { enhancement of the } \\
\text { signal intensity after } \\
\text { gadolinium injection }\end{array}$ & Inferolateral & $\begin{array}{l}\text { Cystic spaces } \\
\text { Diffuse hypocellular areas } \\
\text { Verocay bodies }\end{array}$ & Yes & $\begin{array}{l}\text { Lost to } \\
\text { follow-up }\end{array}$ \\
\hline $\begin{array}{l}\text { Kulkarni } \\
{[7],} \\
2014\end{array}$ & $\mathrm{~F} / 68$ & $\begin{array}{l}\text { Protrusion } \\
\text { Pain } \\
\text { Redness } \\
\text { Watering }\end{array}$ & $\begin{array}{l}\text { Mass in the left } \\
\text { orbit }\end{array}$ & NS & Superior & $\begin{array}{l}\text { Antoni A and } \\
\text { Antoni B areas } \\
\text { Verocay bodies } \\
\text { Hemorrhage } \\
\text { IH - vimentin, } \\
\text { neuron-specific enolase, } \\
\text { S-100 protein positive }\end{array}$ & Yes & No/1 months \\
\hline $\begin{array}{l}\text { Present } \\
\text { case }\end{array}$ & $\mathrm{F} / 84$ & $\begin{array}{l}\text { Protrusion } \\
\text { Inferior } \\
\text { ectropion }\end{array}$ & $\begin{array}{l}\text { Well-demarcated, } \\
\text { oval mass; isodense } \\
\text { compared to } \\
\text { muscle }\end{array}$ & $\begin{array}{l}\text { T1: isointense } \\
\text { T2: heterogeneous, } \\
\text { mostly hyperintense } \\
\text { T2 GE: central } \\
\text { hypointense } \\
\text { component } \\
\text { T1 C+: progressive, } \\
\text { heterogeneous } \\
\text { enhancement; } \\
\text { central enhancing } \\
\text { component }\end{array}$ & $\begin{array}{l}\text { Inferolateral } \\
\text { Intraconal }\end{array}$ & $\begin{array}{l}\text { Antoni A and } \\
\text { Antoni B areas } \\
\text { Verocay bodies } \\
\text { Hemorrhage } \\
\text { Nuclear atypia } \\
\text { IH - S-100 protein } \\
\text { positive }\end{array}$ & Yes & No/3 months \\
\hline
\end{tabular}

CT, orbital computed tomography; MRI, magnetic resonance imaging; T1, T1-weighted images; T2, T2-weighted images; GE, gradient-echo images; C+, contrastenhanced images; IH, immunohistochemical investigation; NS, not stated. 